\title{
O tym, co z relatywizmu nie wynika. Perspektywa współczesnej socjologii wiedzy naukowej
}

\author{
Abstract \\ What relativism does not imply. \\ The perspective of Sociology of Scientific Knowledge
}

The article offers remarks on selected problems of epistemic relativism. The special attention is drawn to some of the stereotypes connected with relativism as it is often perceived as an anti-scientific and anti-realist position implicating cognitive arbitrariness and subjectivity of our judgements and beliefs together with "equal validity thesis". The cultural circulation of these stereotypes is a great challenge to any eduction system and should be given a proper treatment. The article brings forward some of the arguments against these stereotypes based on SSK (Sociology of Scientific Knowledge).

Key words: epistemic relativism, cultural relativism, absolutism, Sociology of Scientific Knowledge Słowa kluczowe: relatywizm poznawczy, relatywizm kulturowy, absolutyzm poznawczy, socjologia wiedzy naukowej

\section{Dwa wstępne zastrzeżenia}

Warto na wstępie opatrzyć niniejsze uwagi kilkoma zastrzeżeniami. Zastrzeżenie pierwsze wydaje się oczywiste, lecz wypada je od razu wypowiedzieć. Otóż współcześnie już nie sposób odnieść się w krótkim tekście do wszystkich niuansów argumentacyjnych pojawiających się w filozoficznych sporach 
o względność poznania ${ }^{1}$. Idea relatywności dołączana jest - z lepszym lub gorszym skutkiem - do wielu odmiennych stanowisk, a sam termin "relatywizm” używany jest we wszystkich niemal sferach filozofii, nauk społecznych oraz przyrodoznawczych ${ }^{2}$. Tym samym relatywizm ma wiele form. Występuje on w licznych przebraniach, jest aktorem wielu narracji i służy różnym celom. Jednocześnie filozoficzny problem relatywizmu nie jest jedynie wielowiekową intelektualną rozgrywką akademików. Obstawanie na pozycjach absolutysty bądź relatywisty (epistemicznego oraz aksjologicznego) ma, między innymi, daleko idące konsekwencje społeczno-edukacyjne. Zagadnienie kryterium rozstrzygalności w obliczu doświadczenia pluralizmu kulturowo-światopoglądowego należy uznać za jeden $\mathrm{z}$ istotnych problemów teoretycznych, przed którym stoją między innymi współczesne teorie edukacji. Zwłaszcza najważniejsze z implikacji teoretycznych, o które podejrzewany jest relatywizm, nie mogą pozostać bez komentarza ze strony żadnego odpowiedzialnego systemu edukacji ${ }^{3}$.

Bez wątpienia zawsze można skwitować rzecz żartobliwie, że z pewnego punktu widzenia relatywizm jest słuszny, natomiast $z$ innego - niesłuszny. Pokusa ucieczki w ironiczną narrację jest w tym przypadku spora. Cel poniższych uwag ma jednak charakter raczej pragmatyczny. Przyjrzę się przede wszystkim kilku generalnym teoretycznym zastrzeżeniom dotyczącym teoretycznych konsekwencji relatywizmu poznawczego w świetle tezy o wielości niewspółmiernych kulturowo-społecznych kryteriów racjonalności oraz odmienności

1 Liczba prac podejmujących teoretyczny problem relatywizmu jest imponująca. Jeśli chcielibyśmy bowiem wskazać jakiś żywotny współcześnie ogólny problem filozoficzny o zasięgu znacznie wykraczającym poza kręgi akademickich specjalistów, to z powodzeniem możemy wskazać na szeroko rozumiany spór o relatywizm. Współczesne globalne wyzwania wielokulturowości, zagadnienie granic tolerancji politycznej i światopoglądowej, spory o sens pojęcia wolnomyślicielstwa, poszukiwanie ponadkulturowego uniwersalnego kodu moralnego - we wszystkich tych kwestiach można rozpoznać teoretyczny spór o relatywność bądź absolutność tego, co prawdziwe, ważne, moralne, właściwe itd.

2 Podstawowych argumentów i wątków we współczesnym sporze o relatywizm dostarczają między innymi Hollis, Lukes, 1982; Feyerabend, 1987; Margolis, 1991; Geertz, 2000; Rorty, 1999; Baghramian, 2004; Harre, Krausz, 1996; García-Carpintero, Kölbel, 2018. Reprezentatywnymi przykładami stanu współczesnej debaty są między innymi Putnam, 1987; Searle, 1995; Boghossian, 2006; Kusch, 2017; Seidel, 2014. W Polsce warto sięgnąć między innymi do: Motycka, 1984; Czerniak, 1992; Mokrzycki, 1992; Chmielewski, 1997; Leszczyński, 2013; Grobler, 2000.

3 Nawiązując do poglądów Wernera Jeagera w kwestii antycznych źródeł pedagogiki, Bauman pisze, iż „sama idea edukacji wyrasta $z$ dwóch nierozłącznych przesłanek: że pod kruchą powierzchnią zróżnicowanych i zmiennych ludzkich doświadczeń tkwi twardy grunt niezmiennego porządku świata i że równie twarde i solidne są prawa rządzące ludzka naturą. Pierwsze założenie uzasadniało konieczność i pożytki płynące z przekazywania wiedzy (...). Drugie dodawało nauczycielom wiary i pewności siebie potrzebnej do wykuwania osobowości uczniów" (Bauman, 2003, s. 110). 
standardów formowania przekonań i ich uzasadniania. Relatywizm w kwestii poznania wydaje się implikować, zdaniem jego krytyków, trudne do zaakceptowania wnioski dotyczące natury oraz statusu poznawczo-metodologicznego nauki współczesnej ${ }^{4}$. Pierwszym częstym zarzutem wobec relatywizmu poznawczego jest wszak jego antynaukowy charakter oraz jego antynaukowe konsekwencje. Antyrelatywiści stają zwykle w obronie tezy o racjonalności rozwoju wiedzy naukowej (między innymi Popper, 1972, 1994; Lakatos, 1977; Laudan, 1996) oraz jakiejś formy realizmu teoriopoznawczego (między innymi Bricmont, Sokal, 2004; Norris, 1997; Boghossian, 2006; Doppelt, 2014). Twierdzi się często, iż „realizm uznaje, że nauka znajduje dostęp do, w znacznej mierze niewidzialnego, uniwersum rzeczywistych obiektów, procesów, mechanizmów i rodzajów naturalnych leżących u podłoża świata zjawisk. Nauka z powodzeniem uwalnia się od społecznych i historycznych okoliczności i ujawnia źródła oraz naturę zjawisk:

(...) Relatywizm uznaje $\mathrm{z}$ kolei, że to, co podawane jest za prawdę naukową, odzwierciedla raczej znaczną liczbę czynników pozapoznawczych. Zgodnie z tym stanowiskiem uzasadnienia twierdzeń naukowych zależą od warunków czy też zasad, których uniwersalności nie sposób wykazać, a które związane są z partykularnymi społecznymi, kulturowymi czy historycznymi praktykami (Carrier, Roggenhofer i in., 2004).

To sugeruje istnienie teoretycznej opozycji między realizmem a relatywizmem epistemicznym i wiąże się z drugą rzekomą implikacją relatywizmu. Chodzi o epistemologicznie idealistyczny oraz subiektywistyczny charakter relatywizmu. Trzecią tezą wiązaną $\mathrm{z}$ relatywizmem wydaje się tak zwane twierdzenie o równoważności (ang. equal validity thesis). Na przykład już na wstępie swojej wpływowej książki Boghossian (2006) charakteryzuje relatywizm właśnie $\mathrm{w}$ ramach tezy o równoważności (równowartości). Zgodnie z nią ,istnieje wiele zasadniczo odmiennych, lecz jednocześnie równoważnych (ang. equally valid) sposobów poznawania świata, a nauka jest po prostu tylko jednym $z$ takich sposobów (Boghossian, 2006, s. 2). Odnotowuje on przy tym krytycznie fakt szerokiego oddziaływania tak pojmowanego relatywizmu jako składnika współczesnego klimatu intelektualnego: „Na dużym obszarze hu-

4 Sprawa ta wiąże się ściśle również z debatami akademickimi. Relatywizm bywa czasem wiązany z postmodernistycznymi wypowiedziami na temat nowożytnej nauki i jej osiągnięć. Do najbardziej znanych przykładów należy tak zwana parodia Sokala związana z jego przewrotnym artykułem Transgressing the Boundaries: Towards a Transformative Hermeneutics of Quantum Gravity, opublikowanym w (nierecenzowanym wtedy) czasopiśmie „Social Text” w 1996 roku. Artykuł Sokala był mistyfikacją i zarazem celną krytyką sprzeniewierzania się standardom rzetelności intelektualnej w literaturze przedmiotu. Rozszerzoną krytykę tych zjawisk zawiera Sokal, Bricmont, 2004. 
manistyki oraz nauk społecznych taki rodzaj 'postmodernistycznego relatywizmu' w kwestii wiedzy osiągnął już status ortodoksji” (Boghossian, 2006, s. 2)5.

Zastrzeżenie drugie: pojęcie relatywizmu - jak każde pojęcie - ma swoją historię. Historia filozoficznego konceptu relatywizmu nie jest długa. W debatach akademickich termin „relatywizm” pojawia się w XIX wieku' ${ }^{6}$. Podobnie jest z tym, co w naszej tradycji intelektualnej nazwaliśmy (z właściwą tej tradycji skłonnością do agregowania różnorodnych zjawisk w semantycznej abstrakcji) „problemem relatywizmu”. Za bezpośrednie źródło współczesnej debaty nad relatywizmem poznawczym w nauce przyjmuje się zwykle wystąpienie Thomasa Kuhna w 1969 roku. Zaproponował on koncepcję niekumulatywnej zmienności historycznej nauki polegającej na rewolucyjnej wymianie niewspółmiernych (między innymi semantycznie) paradygmatów. Idea wielości odmiennych i niewspółmiernych paradygmatów (macierzy dyscyplinarnych) postawiła w centrum dwudziestowiecznych kontrowersji epistemologicznych kwestie historyczności oraz relatywności poznania naukowego.

Książka Kuhna - i żywa debata, jaką wywołała w latach siedemdziesiątych XX wieku - nie pojawiła się w próżni teoretycznej. Grunt pod jej powstanie oraz recepcję przygotowany był przez wcześniejsze społeczno-kulturoznawcze interpretacje późnego Wittgensteina (na przykład Winch, 1964), dyskusje wokół trzech tez o niezdeterminowaniu W.V.O. Quine’a $(1960,1969)$ oraz osiągnięcia na gruncie antropologii kulturowej (Whorf, 2002). Sam Kuhn powoływał się również na inspirację ideami stylu myślowego oraz kolektywu myślowego wypracowanymi przez Ludwika Flecka (1935) w latach trzydziestych $\mathrm{XX}$ wieku. To w ten sposób, dodajmy, koncepcja paradygmatycznego rozwoju nauki Kuhna zyskała swoje socjologiczne interpretacje. Indywidualny podmiot badawczy utracił swoją autonomię i stał się uczestnikiem danej kulturowej tradycji poznawczej. Tradycja ta wyposaża naukowca w swoiste sposoby doświadczania i poznawania tego, co uznawane jest za „naturę” na gruncie tej tradycji. Tym samym uznaje się, że

\footnotetext{
5 Za podobnym rozumieniem relatywizmu - jako formy equal validity thesis - wydaje się zresztą opowiadać wielu innych autorów oferujących swoje typologie relatywizmu. Na przykład Moroz (2018) pisze: „różne społeczeństwa i kultury mają odmienne systemy uzasadniania swojej wiedzy i wszystkie one traktowane są przez relatywistów jako równoważne. Nie można więc powiedzieć, że któryś z systemów jest lepszy lub gorszy, nie istnieje obiektywny, uniwersalny sposób ich oceny" [s. 17, podkr. M.W.].

6 Jak dowiadujemy się ze Stanford Philosophy Encyclopedia, termin relativismus pojawia się po raz pierwszy w leksykonie, który opracował niemiecki filozof Wilhelm Traugott Krug (1838). Z kolei w literaturze anglojęzycznej przyjmuje się, że termin „relatywizm” po raz pierwszy pojawia się w pracy Johna Grote’a (1865).
} 
każde poznanie jest działaniem społecznym (...) niemożliwy jest naprawdę izolowany badacz, niemożliwe jest ahistoryczne odkrycie (...). Izolowany badacz bez uprzedzeń i tradycji, bez działających na niego sił społeczeństwa myślowego (...) byłby ślepy i bezmyślny. Myślenie jest czynnością zbiorową. (...) Co myślimy i jak widzimy, zależy od kolektywu myślowego, do którego należymy (Fleck, 1935, s. 75).

Spojrzenie społeczno-historyczne pozwala też dostrzec, że kulturowe doświadczenie relatywności wydaje się nam towarzyszyć od zawsze. Doświadczenie napięcia między relatywnością a absolutnością form życia pojawia się bowiem wszędzie tam, gdzie ludzie stykają się z wielością odmiennych sposobów życia, gdzie dostrzegają skuteczność tych sposobów oraz gdy uświadamiają sobie odmienność konceptualizacji świata stojącą za różnymi sposobami życia. Co istotne, samo doświadczenie pluralizmu kulturowego nie prowadzi jeszcze do doświadczenia relatywności form życia. Do tego potrzebne jest dodatkowo uświadomienie sobie, że postrzeganą przez nas odmienność możemy, owszem, próbować konceptualizować, lecz możemy to czynić tylko z wykorzystaniem standardów naszej własnej kultury. W tym sensie teoretycznie pierwotną formą relatywizmu okazuje się tak zwany relatywizm kulturowy, a sam spór ma istotną komponentę empiryczną ${ }^{7}$. Połączenie perspektywy epistemologicznej $\mathrm{z}$ antropologiczno-kulturoznawczą oraz socjologiczną ma zasadnicze znaczenie dla samej próby określenia czym, koniec końców, relatywizm jest. Interesującą formę takiego projektu teoretycznego oferuje współczesna socjologia wiedzy naukowej (SSK - Sociology of Scientific Knowledge) w wersji propono-

7 Trudno przecenić rolę dla rozwoju refleksji nad relatywizmem materiału teoretyczno-empirycznego dostarczonego przez antropologów, etnografów i lingwistów w XIX i XX wieku. Jego omówienie wymagałoby oddzielnego opracowania. Wspomnieć wypada tylko o dwóch klasycznych już pozycjach. Pierwszą z nich są badania kultury plemienia Azande przeprowadzone przez E.E. Evans-Pritcharda (1973) wraz z komentarzami Petera Wincha zawartymi w tekście Understanding a Primitive Society (1964, s. 307-324), przeprowadzonymi z punktu widzenia filozofii późnego Wittgensteina. Do kanonu argumentów relatywistów kulturowych zalicza się też tak zwaną hipotezę Sapira-Whorfa opartą na etnolingwistycznych badaniach nad językiem Indian Hopi w Arizonie (Whorf, 2002). Whorf pisze: „do natury praktyk językowych należy zatem to, że ukierunkowują one myślenie i percepcje jednostek partycypujących w danym systemie praktyk (żyjących w ramach określonej formy życia). Struktura języka ma więc zdolność do modelowania i generowania nawet najbardziej fundamentalnych kategorii ontologicznych i kosmologicznych (czas-przestrzeń, materia), z którymi społeczności identyfikują swoje formy życia. Nieuświadamiany wpływ gramatycznego zaplecza na formy myślenia i percepcji użytkowników danego języka oznacza też, że (...) nikt nie potrafi opisać rzeczywistości całkowicie bezstronnie; wszystkich nas krępują pewne prawidła interpretacji nawet wówczas, gdy sądzimy, że jesteśmy wolni (...). Dochodzimy tu do nowej zasady relatywizmu: postrzegający nie tworzą sobie tego samego obrazu świata na podstawie tych samych faktów fizycznych, jeśli ich zaplecza językowe nie są podobne lub przynajmniej porównywalne (2002, s. 286). 
wanej przez tak zwany mocny program socjologii wiedzy Szkoły Edynburskiej (Barnes, Bloor, 1992; Barnes i in., 1996; Kusch, 2002).

$\mathrm{Na}$ jej obszarze udaje się pogodzić naukową, materialistyczno-naturalistyczną koncepcję poznania i języka ze spójnym, dobrze uargumentowanym stanowiskiem relatywistycznym. Istnieją mocne argumenty, że człowiek, jako zwierzę społeczne, jest instynktownym realistą i ma naturalna predylekcję do używania języka w trybie obiektywistycznym. Właściwym obszarem badania takich zjawisk będą zatem, na przykład, psychologia społeczno-poznawcza lub antropologia kognitywna. Realizacja takiego przedsięwzięcia wiąże się, miedzy innymi, $z$ empirystycznym i naturalistycznym podejściem w kwestii języka. Odpowiedź na pytanie, skąd w ogóle bierzemy nasze pojęcia i standardy myślenia, jest tu naturalistyczna oraz antyplatońska ${ }^{8}$.

Podejście takie nie stoi w sprzeczności z relatywizmem poznawczym. Przeciwnie, z perspektywy mocnego programu SSK relatywizm poznawczy okazuje się stanowiskiem naukowym.

\section{Relatywizm poznawczy a metafora wielości map}

Możliwe jest wyznaczenie wspólnej wymienionym wyżej obszarom teoretycznym - od późnego Wittgensteina przez socjologię i antropologię kultury po filozofię nauki i języka - linii rozumowania, która doprowadziła badaczy do dwudziestowiecznych koncepcji relatywizmu poznawczego. Linia ta wychodzi od - dość swobodnie rozumianej - idei holizmu semantycznego oraz holizmu przekonań9. Sednem tej idei jest teza, wedle której własności semantyczne i propozycjonalne wszystkich wyrażeń i treści wchodzących w skład pewnej całości (systemu pojęć czy też sieci przekonań) wzajemnie się determinują. Ideę tę przejęła również SSK. Zgodnie z nią wiedza ludzka - uzasadnione i grupowo podzielane przekonania - przybiera postać całościowych, rozwijających

8 Podeście empirystyczne w kwestii języka wiąże się ściśle z tak zwaną semantyką finitystyczną opracowaną na gruncie edynburskiej SSK. Dla finitysty „nie istnieje nic takiego jak 'ekstensja' terminu czy pojęcia. Jeśli słowo ‘ekstensja’ ma być używane, to zupełnie w innym sensie (...). Bez rozumianych tradycyjnie (zamkniętych) ekstensji nie mamy już jednak wyrażeń o z góry ustalonej treści (...). Nie istnieje klasa rzeczy poprzedzająca akt klasyfikacji (...). Zawartość klasy zależy od decyzji, które muszą jeszcze być podjęte, a zatem jeszcze nie istnieją. Pojedyncze rzeczy, przedmioty, poprzedzają te decyzje, lecz nie klasy tych rzeczy. Teza ta oznacza, że 'ekstensje', tak jak rozumieją je filozofowie, nie istnieją" (Bloor, 1997, s. 26).

9 Problem holizmu w filozofii języka jest złożony i wciąż debatowany od czasu jego wprowadzenia przez Quine’a (1953). Na potrzeby niniejszego artykułu wystarczyć nam musi jedynie zasygnalizowanie sedna tej idei. 
się przez społeczne użycie, sieci pojęć i przekonań (por. Hesse, 1974). Sieci takich można wskazać w historii wiele i mogą się one od siebie znacząco różnić. Rozpatruje się je zarówno w trybie historycznym (na przykład jako tradycje epistemiczne czy po prostu „epoki”), jak też antropologiczno-kulturoznawczym (jako kultury czy formy życia). Stosowanie kategorii „paradygmatu”, „systemu pojęciowego”, „siatki językowej”, „ogólnych teoretycznych punktów widzenia”, „stylu myślowego” czy też wreszcie - najogólniej - kategorii „języka” bądź „kultury” sygnalizuje holistyczne i zarazem diachroniczne badanie zmienności ludzkiej wiedzy ${ }^{10}$. Stosowane czasem przez socjologię wiedzy naukowej pojęcie kultury jest zwykle na jej gruncie uogólniane do tego, co na przykład Kmita (1983) określił jako „rzeczywistość myślowa”. Stanowi ją klasa „przekonań dotyczących zarówno sfery ontologicznej (określających zatem, co istnieje), epistemologicznych (określających, jak to coś poznać) oraz aksjologicznych (światopoglądowych, określających nadrzędne, ostateczne cele życiowe, sposoby ich osiągania, a także pochodne wobec nich przekonania moralne oraz estetyczne). Wspomniane przekonania są powszechnie podzielane w jakiejś społeczności, przy czym część owych przekonań to przekonania jawne (akceptowane), a część (większa) to przekonania ukryte (respektowane)" (Szahaj, 2011, s. 183) ${ }^{11}$.

Pomyślmy zatem o tak rozumianych kulturach czy tradycjach poznawczych (myślowych), jak o różnych rodzajach map - geologicznej, politycznej, klimatycznej - które możemy sporządzić jako trafne odzwierciedlenia tego samego terenu. Analogia wydaje się chwytać sedno relatywizmu wypracowanego na gruncie nowoczesnej socjologii wiedzy naukowej, za którym będę się dalej opowiadać ${ }^{12}$. Wypunktujmy kilka cech tej metafory:

10 Tego typu badań - których źródła leżą w szeroko rozumianym neokantyzmie - dostarczają między innymi holistyczne analizy typu Weltanschauung, które „ujmują teorie jako coś ściśle powiązanego z szerszymi układami pojęciowymi, a nawet szerzej: intelektualnymi, w rodzaju ogólnej perspektywy, obrazu świata. (...) Nauka jest więc elementem szerszej całości, która determinuje rodzaje pytań i kryteria akceptowalnych odpowiedzi na nie. Określa ona też znaczenia słów i sposoby ich wiązania z przyrodą" (Jodkowski, 1990, s. 92).

11 To wyjaśnia, dlaczego badacze pochodzący z różnych kultur (w sensie etnicznym) zgodnie pracują w międzynarodowych laboratoriach i instytutach naukowych typu CERN. Badacze ci uczestniczą bowiem - w wyniku odpowiedniej edukacyjnej socjalizacji i enkulturacji - w tej samej kulturze (tradycji poznawczej europejskiego przyrodoznawstwa), a zatem w tej samej „rzeczywistości myślowej”. Odpowiedź na pytanie, dlaczego akurat ta tradycja poznawcza zyskała globalny zasięg, wiąże się zapewne, w jakimś zakresie, z jej skutecznością technologiczno-ekonomiczną. Wnioskowanie $\mathrm{z}$ tego o jej szczególnie uprzywilejowanym epistemicznie dostępie do „rzeczywistości samej” byłoby jednak pochopne.

12 Metafora ta wykorzystywana była między innymi wśród teoretyków relatywizmu na gruncie mocnego programu socjologii wiedzy od lat siedemdziesiątych XX wieku (Barnes, 2011, s. 27). 
1) teren opisywany przez mapy jest realny (materialny) w tym sensie, że istnieje niezależnie od systemów opisów, jakie potrafimy o tym terenie sformułować;

2) odmienność kryteriów tworzenia map wynika z odmienności naszych potrzeb: pytań, na jakie poszukujemy odpowiedzi, problemów, które chcemy rozwiązać i celów, których osiągnięcie ma nam mapa umożliwić;

3) systemy opisu (mapy) powstają w wyniku naszej ludzkiej badawczej interakcji z realnym otoczeniem. W tym sensie mapy, choć stanowią konwencjonalne systemy opisu terenu, nie są jednak arbitralne. Treść mapy jest zależna przyczynowo od przebiegu naszej eksploracji świata;

4) choć różne rodzaje map odnoszą się do tego samego terenu, odmienność standardów ich konstruowania powoduje, że nie istnieje zrozumiały przekład treści jednej mapy na drugą (na przykład geologicznej na polityczną czy administracyjną);

5) odmienne systemy opisu terenu (na przykład mapa geologiczna i polityczna) mogą być z biegiem czasu korygowane i udoskonalane - każde jednak według swoich standardów. Trafność mapy oceniamy po tym, jak skutecznie pomagają nam one orientować się w terenie.

To ostatnie, pragmatyczne, kryterium należy rozumieć szeroko: „orientacja w terenie" jest tu, naturalnie, rozumiana metaforycznie. Dotyczyć może ona zarówno rozwiązywania problemów przeżycia biologicznego, jak i problemów psychologicznych wynikających ze złożoności ludzkiej egzystencji i wielości możliwych odpowiedzi na pytanie, czym jest i co w ogóle znaczy udane, interesujące, satysfakcjonujące życie.

\section{Anatomia relatywizmu, czyli szkielet argumentacyjny}

Wygodnym punktem wyjścia koncepcji relatywistycznych jest proste spostrzeżenie, że przedstawiciele odmiennych kultur (na przykład K1 i K2) odmiennie klasyfikują swoje otoczenie, używają bowiem odmiennych językowych kategoryzacji. To powoduje, że w ramach K1 i K2 rozwijają się odmienne konceptualizacje świata, z których uczestnicy K1 i K2 budują odmienne uogólnienia oraz przekonania. W rezultacie, co jest, a co nie jest 'faktem', jest zatem w K1 i w K2 ustalane odmiennie. Odmiennie też w K1 i K2 rozstrzyga się, co jest, a co nie jest argumentem w danej sprawie. Tym sposobem odmienne kultury formują i rozwijają odmienne tradycje poznawcze. Nie istnieje przy tym uniwersalne kryterium rozstrzygania, która kultura opisuje i wyjaśnia rzeczy prawdziwie (adekwatnie, poprawnie), a która nie. Po pierwsze, Natura (empiria) takiego 
neutralnego kryterium bowiem nam nie dostarcza (między innymi percepcje uczestników K1 i K2 są zdeterminowane aparatem pojęciowym ich kultur). Po drugie, $\mathrm{K} 1$ oraz K2 wytwarzają również odmienne refleksyjne metaprzekonania: przekonania co do tego, jak przekonania w ogóle powstają i dlaczego są one czasem podtrzymywane lub odrzucane.

Nie znaczy to wcale, że Natura - zewnętrzna, pozakulturowa rzeczywistość - nie ma żadnego wpływu przyczynowego na kultury. Tradycje poznawcze nie są arbitralne. Mówimy raczej, że może być wiele różnych, wewnętrznie spójnych kulturowych tradycji poznawczych, które pozostają w zgodnej i skutecznej interakcji z przyczynowym wpływem natury.

Zaangażowany tu relatywizm oznacza, że każdy z systemów opisu i argumentacji (form życia K1 i K2) jest prawdziwy (sensowny), ale tylko w granicach formy życia danej kultury. Powyższe pozwala zrekonstruować relatywistyczny szkielet argumentacyjny. Wygodnie jest wypunktować jego kolejne kluczowe elementy składowe:

1) dowolny obiekt kulturowy (w tym ten uznawany w danej kulturze za naturalny) jest $\mathrm{w}$ istotnym stopniu zależny od skonwencjonalizowanych, historyczno-kulturowych układów odniesienia;

2) zależność z pkt. 1 powoduje, że obiekty jawią się w naszym doświadczeniu na wiele odmiennych sposobów;

3) odmienność obiektów kulturowych bywa tego rodzaju, że sposoby, o których mowa w pkt. 2, są niewspółmierne (to jest brak nam wspólnej miary, by je sensownie porównywać);

4) idea, że możemy dociekać tego, która z odmiennych kulturowych tradycji „tak naprawdę ma rację”, opiera się na założeniu, że istnieją jakieś niezależne od kulturowych (to jest absolutne) standardy dociekań w ogóle. Relatywizm zakłada jednak, że myślenie, w tym formy autorefleksji, jest zawsze częścią złożonej i przygodnej tradycji historyczno-kulturowej.

Zebranie elementów szkieletu argumentacyjnego prowadzi nas z reguły i zwykle rozsądnie - do jakiejś uogólniającej definicji relatywizmu. Relatywizm określamy tedy, na przykład, jako stanowisko filozoficzne, które „odrzuca tezę o istnieniu obiektywnych, ostatecznych oraz fundamentalnych twierdzeń o świecie, które mają charakter powszechnie obowiązujący" (Chmielewski, 1997, s. 52). Możemy też taką definicję komentować, powiadając, iż „nie mamy żadnego punktu Archimedesowego; mówimy zawsze językiem pewnego czasu i miejsca; niemniej słuszność lub błąd tego, co mówimy, jest tylko tu i teraz" (Putnam, 1998, s. 345). Ewentualnie możemy również próbować dookreślić na przykład relatywizm wiedzy jako stanowisko, według którego „wiedza zależy od różnorodnych czynników relatywizujących, między innymi epoki, kultury, gatunkowych predyspozycji, indywidualnej perspektywy. Relatywizm wie- 
dzy to zatem pogląd, że nie istnieje wiedza o charakterze uniwersalnym czy niekontekstowym" (Moroz, 2018, s. 7).

Zastrzec jednak warto, że istnienie zależności między kontekstem norm miejsca i czasu a systemem wiedzy (i jej uzasadniania) nie prowadzi jeszcze, formalnie rzecz biorąc, do relatywizmu epistemicznego ${ }^{13}$. Sam kontekstualizm poznawczy nie jest wszak jeszcze relatywizmem. Podobnie konwencjonalizm nie prowadzi nas koniecznie do relatywizmu. Świadomość pluralizmu kontekstów (czy konwencji społeczno-kulturowych) może być wręcz argumentem na rzecz antyrelatywizmu. Jeśli bowiem udaje się ustalić (a nawet sformalizować) zależność (przekład) między odmiennymi kontekstami (konwencjami), to uzyskujemy jednolity i wieloaspektowy właśnie obraz przedmiotu poznania. Sytuacja się jednak zmienia, gdy kontekstualizm bądź konwencjonalizm uzupełniony zostaje o tezęo niewspótmierności treści rezultatów poznawczych determinowanych odmiennymi kontekstami czy konwencjami.

\section{Kultury są bytami otwartymi, a standardów krytyki jest wiele}

Absolutyzm nie kwestionuje w zasadzie istnienia zjawiska uwarunkowania myślowej relacji z rzeczywistością. Uznaje jednak, że istnieją sposoby eliminacji bądź kontrolowanej minimalizacji wpływu tego warunkowania. Jako strategie antyrelatywistyczne (de-relatywizujące) proponuje się na przykład koncepcje dotarcia do jakiejś jednorodnej, elementarnej podstawy rzeczywistości, której uniwersalność wynikałaby z tego, że poprzedza ona wszelkie uwarunkowania ludzkiego poznania ${ }^{14}$. Inną strategią miałaby być na przykład zdolność rozumu do transcendowania własnych uwarunkowań przez krytyczna (auto)refleksję, zwłaszcza nad własną świadomością metodologiczną i jej standardami. Tradycja sprzyjająca kulturowej roli tak pojmowanej uniwersalnej formy rozumno-

13 Dodajmy, że uwaga o „kontekście podmiotowym” jest w zasadzie wprowadzeniem kategorii konwencjonalizmu jako determinanty podmiotowej przekonań i standardów. Sam konwencjonalizm, podobnie zresztą jak i konstruktywizm, nie prowadzi jednak jeszcze do relatywizmu (por. Leszczyński, 2013).

${ }_{14}$ Ten trop, jak się zdaje, podejmował już Kartezjański metodyczny sceptycyzm kontynuowany przez Husserlowską redukcję transcendentalną. Choć trop ten ma do dziś swoich zwolenników, program filozoficznego dotarcia do tego, co pewne i nieuwarunkowane - do ostatecznej istotowej podstawy rzeczywistości (odsłonięcia czystej świadomości) za pomocą techniki epoché, nie zakończył się powodzeniem. Por. na ten temat choćby Kołakowski, 2003. 
ści dostarczałaby, być może stopniowo, niekorygowalnego, ponadczasowego i adekwatnego odniesienia poznawczego do przedmiotu poznania ${ }^{15}$.

Interesującymi i dalekimi od scjentystycznej naiwności przykładami takiej racjonalistycznej derelatywizacji poprzez rozumną krytykę były między innymi propozycje Karla Poppera oraz Jurgena Habermasa. Ten ostatni, na przykład, oferuje nam katalog cech pozwalający rozróżniać między tradycjami/ kulturami myślącymi „mitycznie”, to jest utrwalającymi niekrytyczny, nienaukowy obraz świata, oraz tradycjami/kulturami myślącymi „racjonalistycznie”, to jest wspierającymi modyfikowanie swojego obrazu świata pod wpływem krytyki. Po pierwsze, obraz świata w kulturze mitycznej - mit - jest zastygłym, nienaruszalnym schematem totalnym, którego kultura mityczna nie poddaje krytyce. Po drugie, mit jest skonkretyzowany i jednorodny. Wszystko ma w nim swoje niezmienne miejsce. Mit jest też urzeczowiony w tym sensie, że nie funkcjonuje w nim rozróżnienie na język i jego referencję. Po trzecie, kultury mityczne hamują działania krytyczne - są zwłaszcza zamknięte na krytykę własnego języka - i w tym sensie są irracjonalistyczne. Po czwarte, kultury promujące i wspierające działania krytyczne prezentują niejako „wyższą formę rozumności”: potrafią rozróżniać między tym, co społeczne, a tym, co indywidualne, oraz umieją przeprowadzać krytykę języka, odwołując się do jego referencji. Po piąte, tradycje racjonalistyczne są , antydogmatyczne”, czyli zdolne do autorefleksyjnej rewizji swoich elementów składowych w świetle krytyki ${ }^{16}$.

Nie mamy tu, niestety, miejsca, by podążać dalej tropem tej - pasjonującej skądinąd - debaty nad rolą myślenia refleksyjno-krytycznego w historii i o możliwym wpływie tej formy myślenia na kulturowe doświadczanie pluralizmu i relatywności form życia. Wystarczyć nam musi tu wypunktowanie kilku spostrzeżeń sformułowanych w tej sprawie przez socjologów wiedzy naukowej (Barnes, 1995, s. 111-118).

15 Kwestia uniwersalności idei refleksyjnej krytyki jest istotna w sporze z relatywizmem kulturowym. Wzajemna ocena dwóch odmiennych tradycji (na przykład zachodniej liberalnej demokracji oraz bliskowschodniej teokracji) zwykle prowadzi do konfliktu. Żadna ze stron nie uzna bowiem za ważną krytyki, która nie jest przeprowadzona według uznawanych przez nią wartości oraz standardów krytykowania. Z kolei wskazanie na uniwersalne metakryteria oceny odmiennych i rozłącznych zbiorów standardów i przekonań musiałoby dokonać się z jakiegoś trzeciego punktu widzenia, którego wybór musiałby być albo uzasadniony według jakichś kolejnych standardów, albo uznany za arbitralny.

16 Jak czytamy w Habermasowskiej Teorii działania komunikacyjnego, „w świecie mitycznym, (...) językowy obraz świata zastyga w porządek świata i nie może być postrzegany jako schemat interpretacyjny podlegający krytyce" (Habermas, 1984, s. 171). Powyższe przywołanie analiz Habermasa nie aspiruje bynajmniej do wyczerpującej interpretacji poglądów niemieckiego myśliciela na omawiane kwestie. Ma ono raczej charakter instrumentalny, sygnalizujący pewną możliwą figurę argumentacyjną stosowaną w strategiach antyrelatywistycznych. 
Po pierwsze, oświeceniowa teza o wyższości racjonalności modernistycznej opiera się na stereotypowym rozumieniu pojęcia tradycji jako czegoś, co jest intelektualnie restrykcyjne, co ogranicza i zamyka poznawczo. Takie pojęcie mityczności - jako skonkretyzowanej fantazji wynikającej z niewiedzy kultur przednaukowych - jest składową potoczności projektu oświecenia i zdrowego rozsądku „nowoczesnych” społeczeństw, a na jego poparcie brak przekonujących dowodów empirycznych. Barnes w związku z tym pyta:

Czy powinniśmy może odwołać się do 'mitycznego obrazu świata' antycznej Grecji? Czy myśl starożytnej Grecji była rzeczywiście zagubiona, urzeczowiona i względnie jednorodna? Czy raczej była ona niezwykle innowacyjna, wnikliwa, głęboka i samoświadoma? (...) Być może bardziej odpowiednie byłoby wskazanie na chrześcijańską teologię? Czyż nie jest to paradygmatyczny przykład 'myśli tradycjonalnej' ery przednowoczesnej? Jeśli tak byłoby $\mathrm{w}$ istocie, czy nie należy też jednak pamiętać, że okres ten można widzieć jako ogromny skłębiony teatr herezji, innowacji, pełen niekończących się debat, konfliktów, ludzkiej zmyślności i pomysłowości? A gdy już jesteśmy gotowi pytać, czy ortodoksja panująca przez wieki nie była po prostu jedną z herezji, która akurat zwyciężyła, to czy z kolei nie prowadzi to nas do pytania o to, czy owo sugerowane 'zamknięcie' właściwe mitycznym obrazom świata w ogóle powinno być przypisywane 'obrazom świata’ czy ‘tradycjom’ czy może raczej zawziętości pewnych ludzi (Barnes, 1995, s. 126).

Po drugie, dane antropologiczno-kulturoznawcze wydają się sugerować, że refleksyjność i krytycyzm są uniwersalnymi składnikami ludzkiego działania. Są one obecne we wszystkich tradycjach poznawczych i kulturach. Nowożytna tradycja naukowa nie jest pod tym względem żadnym wyjątkiem: „(..) refleksyjność jest ciągłym i niezbędnym warunkiem rozwoju każdej tradycji - również do tego, by utrzymywać utworzoną tradycję w stabilnym i niezmienionym stanie" (Barnes, 1995, s. 124).

Po trzecie, skoro myślenie refleksyjne jest niezbędnym składnikiem stabilnego rozwoju każdej tradycji, to teza o „wyższej refleksyjności społeczeństw oświeconych" okazuje się powtarzającą się figurą w historii ludzkiego myślenia i w jakiejś formie pojawia się we wszystkich tradycjach: „refleksyjność musi odgrywać raczej stabilizującą niż 'krytyczną' rolę: sprzężenie zwrotne staje się bowiem tym, co umożliwia stabilność systemu o zróżnicowanych elementach. Tam, gdzie system składa się z odmiennych elementów i mimo to pozostaje jednym systemem, elementy muszą być z sobą w interakcji” (Barnes, 1995, s. 124). Jak stwierdza Barnes: „mit Oświecenia jest stary jak świat” (s. 117).

Pora przejść teraz do próby zebrania tego, co było wyżej powiedziane. 


\section{Tezy o relatywizmie poznawczym z perspektywy SSK}

Zgodnie z SSK każdy relatywizm oznacza odrzucenie idei absolutności poznawczej. Oznacza to, że - dla relatywisty - nie istnieje sposób, by sensownie używać pojęcia „absolutności” w odniesieniu do kategorii wiedzy i poznania. Zdaniem relatywistów nikt nie jest $w$ stanie sformułować żadnej absolutnie ważnej tezy czy standardu. Relatywiści utrzymują, że z samej natury ludzkiego poznania wynika, że sformułowanie tezy absolutnie ważnej poznawczo jest niewykonal$n e$. Relatywizm jest zatem stanowiskiem dotyczącym kwestii natury i granic ludzkiego poznania.

Relatywiści twierdzą, że ludzie nie posiadają, i nigdy nie będą w stanie posiąść, wiedzy absolutnej. (...) Dla relatywisty wszystkie nasze przekonania są produktem ograniczeń naszej ludzkiej natury jako zwierząt społecznych oraz są do niej zrelatywizowane (...) [Przekonania] nie mogą przekraczać machinerii naszych mózgów i doznań naszych zmysłów, naszych kultur i tradycji, na których się opieramy (Bloor, 2007, s. 251) ${ }^{17}$.

Rzecz jasna, bywa, że wypowiadający dane twierdzenie ma poczucie, że oto wygłasza sąd o absolutnej ważności czy prawdziwości. Bywa, że rozstrzygając jakiś problem, my sami mamy poczucie obezwładniającej mocy stosowanych standardów intelektualnych i tym samym ich absolutnej poprawności. Należy jednak odróżniać przygodne, kulturowo zdeterminowane stany mentalne podmiotów poznających od faktycznego charakteru formułowanych przez nie stwierdzeń.

Przyjrzyjmy się zatem „tezom o relatywizmie” (TR) z perspektywy współczesnej socjologii wiedzy naukowej. Z konieczności w krótkim tekście możemy jedynie zasygnalizować podstawowe tropy, jakimi podąża argumentacja SSK w kwestii relatywizmu poznawczego.

TR nr 1. Relatywizm poznawczy nie implikuje subiektywizmu poznawczego.

Subiektywizm poznawczy zawsze implikuje relatywność wiedzy. Odwrotna zależność jednak nie zachodzi. Można bowiem być relatywistą, to jest kwestionować absolutną ważność wiedzy i poznania, nie uznając indywidualizmu epistemologicznego i metodologicznego. Szeroko rozumiana indywidualistyczna koncepcja wiedzy - choć implikuje relatywizm epistemiczny - popada w trudności teoretyczne. Stoi ona również w jawnej sprzeczności z tym, jak

17 Bloor dodaje, że możemy, rzecz jasna, wzmacniać i uzupełniać nasze możliwości zmysłowe i intelektualne za pomocą mikroskopów, teleskopów czy komputerów. Lecz ostatecznie to do nas należy „zrozumienie i interpretacja dostarczanych przez nie danych. A to prowadzi nas znowu do naszej kultury, która stanowi podstawę naszej interakcji ze światem” (Bloor, 2007, s. 251). 
wiedza i jej nośnik - język - faktycznie funkcjonują w kulturze. Zarówno język, jak i ujęta w nim wiedza są bowiem zjawiskami ponadindywidualnymi, to jest przekraczają indywidualne umysły podmiotów danej zbiorowości. Język i wiedza stanowią naturalne, społeczne fenomeny historyczno-kulturowe. Wciąż zachowują moc klasyczne uwagi Durkheima o nieredukowalnej różnicy między percepcjami i myślami pojedynczego członka wspólnoty a zbiorowo wypracowanymi i akceptowanymi modelami, przekonaniami oraz zinstytucjonalizowanymi reprezentacjami świata (Durkheim, 1990). Podobnie SSK przychyla się do sceptycznych wniosków płynących z Wittgensteinowskiej analizy hipotezy "języka prywatnego" (Wittgenstein, 2000, \$ 243-259). Wiedza zatem jest atrybutem wyłącznie zbiorowości językowo-kulturowej, nie zaś indywidualnego podmiotu. W nim zaś, poprzez procesy socjalizacji, enkulturacji oraz edukacji, dokonuje się transformacja subiektywnych wrażeń i myśli w składniki historycznie ewoluującego, kulturowego korpusu społecznie podzielanych przekonań, to jest w wiedzę (danej wspólnoty) ${ }^{18}$. Tylko tak przekonania mogą zyskać walor intersubiektywności, czyli wyrażalnej językowo treści. I tylko tak - poprzez partycypację w kulturze swojej zbiorowości - jednostka ludzka uzyskuje pełnię swojego człowieczeństwa (Barnes, 2011, s. 23-24).

TR nr 2. Relatywizm poznawczy ani nie implikuje krytyki tradycji nowożytnego przyrodoznawstwa, ani nie kwestionuje ważności ustaleń poznania naukowego.

Broniona przez SSK forma relatywizmu nie kwestionuje idei postępu poznawczego. Relatywizm ten kwestionuje jedynie ideę absolutnego postępu poznawczego oraz absolutnego przyrostu wiedzy ${ }^{19}$. Jak pisze Bloor, „dla relatywisty, nie istnieje i nie może istnieć nic transcendentalnego w historii ludzkich osiągnięć i porażek. Ani wiedza, ani moralność nie mogą mieć charakteru nadprzyrodzonego. Są one zjawiskami naturalnymi, a próba uniknięcia tego wniosku wiedzie na drogę zabobonu i obskurantyzmu” (Bloor, 2007, s. 252).

Co więcej, kwestią rozwagi terminologicznej i pojęciowej jest wstrzymywanie się przed utrzymywaniem opozycji między kategorią „obiektywności” wie-

18 Jak się zdaje, zapoznanie między innymi tego faktu wśród przedstawicieli Koła Wiedeńskiego stało u źródeł porażki poszukiwań absolutnej podstawy wiedzy empirycznej, to jest „czystych i bezpośrednich danych”, które wyrażać by miały „zdania protokolarne”. Szybko zauważył to zresztą na przykład Ludwik Fleck, który ironicznie pytał: „Cóż to za bezpośrednie dane, których trzeba aż tak szukać? W jaki sposób są one bezpośrednio dane, jeśli trzeba się o nie tak spierać?" (Fleck, 1935, s. 62).

19 W tej kwestii SSK czerpie swoje podstawowe idee - i twórczo je rozwija w trybie socjologicznym - z jednej z najważniejszych książek z filozofii nauki XX wieku, to jest ze Struktury rewolucji naukowych Thomasa Kuhna (1962). 
dzy oraz „relatywności” wiedzy. We wspomnianej już typologii relatywizmów zaproponowanej przez Moroza (2018) czytamy między innymi:

Toczone są dyskusje o tym, czy istnieją obiektywnie skuteczne sposoby dowodzenia i procedury uzasadniania twierdzeń. Zgodnie z poglądami relatywistów wszystkie zależne są od kontekstu, w którym powstały (...). Na kontekst składają się normy obowiązujące w danym czasie i miejscu, a nawet czynniki podmiotowe. Zatem różne społeczeństwa i kultury mają odmienne systemy uzasadniania swojej wiedzy i wszystkie one traktowane są przez relatywistów jako równoważne. Nie można więc powiedzieć, że któryś z systemów jest lepszy lub gorszy, nie istnieje obiektywny, uniwersalny sposób ich oceny (Moroz, 2018, s. 8 [podkr. M.W.]).

Powyższe, skądinąd generalnie trafne, uwagi wciąż pozostawiają wątpliwości. Teza o istnieniu obiektywnie skutecznych sposobów dowodzenia nie stoi w sprzeczności z relatywizmem poznawczym proponowanym przez SSK. Nie jest bowiem ona równoważna właściwej antyrelatywistycznej tezie o istnieniu absolutnie skutecznych sposobów dowodzenia. Pojęcie obiektywności jest użyteczne i uprawnione na gruncie relatywizmu poznawczego. Istotne jest tylko spostrzeżenie, że obiektywność wszelkich przekonań, standardów, procedur czy norm nie ma charakteru absolutnego, lecz lokalny i zrelatywizowany do, jak pisze Moroz, „danego społeczeństwa czy kultury” ${ }^{20}$. Relatywizm podkreśla, że dyskurs epistemiczny danej kultury czy tradycji jest zaangażowany ontologicznie: zbiorowe doświadczanie obiektywności (realności) istnienia obiektów i procesów jest warunkiem skutecznej praktyki danej społeczności. Obiekty te (zjawiska, procesy i prawidłowości) są uznawane w danej kulturze za istniejące niezależnie od wszelkich kultur (Więcław, 2005, s. 17). To samo dotyczy „obiektywnej skuteczności” stosowanych w danej kulturze procedur i standardów uznawanych przez jej uczestników za sposób docierania do własności tych obiektów. Relatywizm w wersji tu przeze mnie omawianej zaznacza jedynie, że żadne $\mathrm{z}$ tych kulturowych osiągnięć nie ma charakteru absolutnie obiektywnego.

Przyjąwszy zatem punkt widzenia SSK, relatywista poznawczy nie ma problemu z przyjęciem faktu, że wiedza jest obiektywna. Przeczy on jedynie temu, przypomnijmy, że wiedza może być absolutnie obiektywna. Kulturowo skonstruowany przedmiot poznania jest w tym sensie obiektywny, że żadna inna obiektywność świata nie jest i nie może być nam dostępna. Tylko na gruncie jakiejś tradycji poznawczej nasza interakcja w niezależnym od nas świecie jest czymś „realnym i sensownym”. Tym samym również nie potrafimy nadać żadnego innego znaczenia pojęciu „obiektywności” poznania, niż tylko sens rela-

20 Jeśli z kolei uznajemy obiektywność za równoznaczną z uniwersalnością, to takie ujęcie nie obejmuje wszystkich form relatywizmu. Jeśli zaś uznajemy uniwersalność za równoznaczną $\mathrm{z}$ absolutnością, to ujęcie to staje się nieprecyzyjne. 
tywistyczny. Jest to zresztą zrozumiałe. Sama kategoria obiektywności wydaje się odnosić raczej do pewnej uniwersalnej cechy psychospołecznej - rodzaju naturalnego nastawienia członków danej wspólnoty do treści akceptowanych w niej przekonań. W tym sensie kategoria obiektywności jest również starsza od nauki nowożytnej i od niej niezależna (Feyerabend, 1987, s. 35). Z kolei po stronie antyrelatywisty leży kwestia wyjaśnienia, jak to, co - z założenia ponadhistoryczne, konieczne i absolutne, może wkraczać w naturalną historię człowieka $^{21}$.

TR nr 3. Relatywizm poznawczy nie implikuje żadnej z form idealizmu ontologicznego.

Relatywizm nie stoi w sprzeczności ani $\mathrm{z}$ realizmem ontologicznym, ani nawet $\mathrm{z}$ naturalistycznym materializmem. Literatura przedmiotu pełna jest chybionych krytyk relatywizmu przeprowadzanych z pozycji debaty z idealizmem filozoficznym. Dychotomia realizm/idealizm nie wiąże jednak w żaden sposób stron epistemologicznego sporu relatywizm/absolutyzm. Spór w kwestii niezależnego (od ludzkiego poznania) istnienia świata nie dotyczy ze swej istoty sporu o relatywność poznania. Wygodnie jest w tej sprawie przywołać Rorty'ego (2009, s. 24), który - choć nie był socjologiem wiedzy i w zasadzie odżegnywał się od etykiety „relatywisty” - rzecz tę ujął wyjątkowo klarownie: „Należy odróżnić twierdzenie, że świat jest na zewnątrz, od twierdzenia, że prawda jest na zewnątrz [...]. Świat jest na zewnątrz, nie ma tam jednak opisów świata. Tylko opisy świata mogą być prawdziwe bądź fałszywe. Świat sam w sobie - niewsparty opisową działalnością istot ludzkich - taki być nie może"22. Współbrzmi to ze stanowiskiem SSK, gdy na jej gruncie podkreśla się, iż Na-

${ }^{21}$ Bloor widzi tu współczesny, epistemologiczny wariant starego teologicznego problemu inkarnacji, to jest niejako wcielenia tego, co absolutne (to jest ponadhistoryczne), w to, co materialne, przyrodnicze i historyczne.

22 Wypada dla porządku dodać, że istnieją tradycje poznawcze skłaniające się ku odmiennej metafizyce języka. Tradycje te pojmują sam świat jako Tekst, rodzaj Księgi. Ludzkie poznanie zasadza się w tych tradycjach na poprawnym odczytaniu świata, który ontycznie jest, w pewnym istotnym sensie, językowy. Oznacza to, że odpowiedzi na wszelkie ludzkie pytania o świat - będący Tekstem Absolutnym - już są w świecie zawarte i wymagają tylko z ludzkiej strony odpowiednio analitycznej lektury i skrupulatnej interpretacji. Nie sposób oprzeć się wrażeniu, że elementy tej tradycji myślowej - korzeniami tkwiącej w judaizmie i idealizmie platońskim - dają się odnaleźć w nowożytnym racjonalizmie oraz współczesnym podejściu analitycznym. Również tu mamy do czynienia z - rzadko werbalizowanym - przekonaniem, że odpowiedzi kryją się już w języku, w którym dany problem jest sformułowany. Zatem to znaczenia językowe są tu poniekąd właściwym przedmiotem poznania. Poznanie świata musi zatem być rozeznaniem analityczno-logicznym. Tradycja ta, oczywiście, stoi w sprzeczności z szeroko rozumianą tradycją empirystyczną, w ramach której poruszam się w niniejszym tekście. 
tura „nie posiada języka i nie może do nas przemawiać, sugerując przekonania na swój temat" (Barnes i in., 1996, s. 87).

Uwaga ta jest istotna z kilka względów. Po pierwsze, rzecz jasna, można być relatywistą i jednocześnie obstawać na idealistycznych pozycjach $\mathrm{w}$ kwestiach ontologicznych. Przykładem takiego stanowiska, nawet w SSK, jest na przykład propozycja Harry’ego Collinsa (1985). Po drugie, stanowisko antyrealistyczne jest konsekwencją interesującego relatywizmu poznawczego o tyle, o ile kwestionuje on absolutny charakter znaczenia pojęcia korespondencji poznawczej. Dla relatywistów aletycznych istotna jest uwaga, by nie przemycać w samej treści pojęcia prawdy pojęcia absolutności ${ }^{23}$. Relatywiści bowiem nie przeczą możliwości istnienia adekwatnej korespondencji między myślami (sądami) a rzeczywistością. Przeczą jedynie temu, że ta adekwatność może mieć charakter absolutny. Innymi słowy, z proponowanej tu perspektywy relatywiści nie tyle zmierzają do stwierdzenia, że „wszelka dostępna nam wiedza jest pozbawiona cechy absolutnej prawdziwości, ile raczej do wyrugowania $\mathrm{z} n a$ ukowej refleksji nad wiedzą takich pojęć, jak 'absolutna prawdziwość'” (Roszyk, 2015, s. 14) ${ }^{24}$.

Rzecz bowiem w tym, że nie sposób wykazać absolutnej ważności ani jakiegokolwiek użycia kategorii „absolutności”, ani żadnego argumentu na rzecz absolutyzmu poznawczego i aksjologicznego.

TR nr 4. Relatywizm poznawczy nie implikuje tezy o równoważności (ang. equal validity thesis).

Z punktu widzenia niniejszych spostrzeżeń teza ta wydaje się najważniejsza. Twierdzenie to powiada, że konsekwentny relatywista zmuszony jest uznać, iż wszystkie sądy (kultury, ogólne punkty widzenia, strategie i tradycje poznawcze itp.) są w ostatecznym rozrachunku równoważne epistemicznie. Dla relatywisty nie istnieje bowiem kryterium rozstrzygające między istotnie odmiennymi stanowiskami poznawczymi czy, szerzej, myślowymi. Jak wspominałem już wyżej, twierdzenie o równoważności bywa zwykle uznawane za

${ }^{23} \mathrm{Na}$ fakt takiego semantycznego przemycania zwraca uwagę między innymi Bloor, identyfikując podejście absolutysty aletycznego z tak zwanym ontologicznym argumentem Anzelma na rzecz istnienia Boga (który, jak wiadomo, z samej treści pojęcia Boga - bytu absolutnie doskonałego - wywodził konieczność realnego istnienia przedmiotu pojęcia). Podobnie absolutysta z samej treści pojęcia prawdy wnioskuje o istnieniu jej absolutnych realizacji (Bloor, 2007, s. 23).

24 M. Roszyk (2015), referując Bloorowską koncepcję relatywizmu poznawczego, również sugeruje istnienie pewnej zbieżności między podejściem mocnego programu SSK a koncepcjami Rorty'ego, szczególnie w kwestii roli pojęcia prawdy jako istotnego elementu siatki pojęciowej uniemożliwiającej właściwe, naukowe postawienie zagadnienia adekwatności poznawczej. Nie jest jednak do końca jasne, czy Bloor przystałby na przypięcie mu etykietki „antyreprezentacjonalisty”. 
definicyjną składową stanowiska relatywistycznego. Problem (nie)równoważności standardów poznawczych dotyczy kwestii istnienia i możliwości rozpoznania warunków, w których lepiej uzasadnione jest opowiedzenie się, na przykład, za przekonaniem P1 niż przekonaniem P2 (lub uznanie argumentacji A1 za lepszą od argumentacji A2).

Otóż relatywiści nie wątpią w to, że w rozstrzygnięciach poznawczych kluczową rolę grają świadectwa i argumenty. Kwestionują jedynie tezę, że świadectwa i argumenty mogą mieć charakter absolutny. Kwestionują też to, że istnieją absolutne kryteria rozstrzygania, co jest, a co nie jest świadectwem/ argumentem $\mathrm{w}$ danej sprawie. Podstawy do oceny oraz przyczyny konkretnego wyboru między P1(A1) a P2 (A2) nie są zatem absolutne, niemniej sq̨ realne. Są one pragmatyczne, lokalne i kontekstowe. Innymi słowy, mogą istnieć trafne, choć relatywne, podstawy do tego, by przypisywać odmienną ważność/trafność/poprawność odmiennym twierdzeniom. Nie istnieje natomiast - zdaniem relatywistów - absolutne kryterium rozstrzygające, które z uzasadnień jest absolutnie lepsze, a które absolutnie gorsze. Relatywista zgadza się, że racjonalny podmiot uznaje lub odrzuca sądy zależnie od świadectw uznawanych za poznawczo istotne w określonej sytuacji. Jednak kwestia tego, jak owa zależność jest oceniana, jest zawsze sprawą uznawanych przez podmiot konwencji społeczno-kulturowych. Same te konwencje z kolei nie mają charakteru absolutnego. Są one ustawicznie rozwijane i stosowane pragmatycznie.

\section{Uwagi końcowe}

Historia pojęcia relatywizmu nie zakończy się na próbie unieruchomienia jej za pomocą takiej czy innej definicji, która wydałaby się nam - na pewnym etapie - definicją uniwersalną i ponadczasową. Naszych przyszłych sposobów użycia pojęcia relatywności, naszych przyszłych dystynkcji i redefinicji, które uznamy za interesujące i poprawne, nie sposób przewidzieć. Jak sądzę, rozwoju języka, a wraz z tym naszych koncepcji i przekonań, nie sposób ani z góry wyznaczyć, ani zaprojektować. Definiowanie pojęć czy precyzyjne werbalizacje teorii są, rzecz jasna, zawsze możliwe. Tymczasowe usztywnianie semantyczne pewnych obszarów dyskursu bywa czasami intelektualnie uzasadnione i społecznie potrzebne. Niemniej takie zabiegi mają zawsze charakter konwencjonalny i - patrząc z odpowiednio szerokiej perspektywy czasowej - doraźny.

Jest też być może tak, że spór o względność poznawczą i aksjologiczną jest, w jakimś sensie, zakodowany w samej siatce pojęciowej zachodniej kultury. 
Rozstrzygnięcie tego sporu zatem za pomocą środków pojęciowych tej siatki nie jest możliwe. Wiara $\mathrm{w}$ istnienie tego rozstrzygnięcia przypomina wiarę $\mathrm{w}$ istnienie monety, która nie posiada awersu i rewersu. Przekonanie, że spór relatywizmu $\mathrm{z}$ absolutyzmem uda się kiedyś ostatecznie rozstrzygnąć przez cierpliwą, skrupulatną i wnikliwą analizę elementów siatki pojęciowej jest, należy się obawiać, chybione. Debata relatywizmu z absolutyzmem dzieli zresztą los wszystkich sporów filozoficznych opierających się na dualistycznych, elementarnych dychotomiach pojęciowych. Problem relatywizmu - w tej czy innej formie - będzie zatem $\mathrm{z}$ nami zawsze dopóty, dopóki nie porzucimy naszej siatki semantycznej z zakodowanymi w niej regułami używania takich kluczowych w słowniku naszej kultury pojęć, jak „prawda”, „wiedza”, „,rzeczywistość”, „pewność, „konieczność”, „relacja” itp. ${ }^{25}$. Słownik ten nie został nam wszak zesłany $\mathrm{z}$ niebios. Jest on produktem społeczno-historycznym, wytworem przygodnych i złożonych procesów kulturowych. Sposoby użycia tego słownika wyznaczają przestrzeń nie tylko możliwych do sformułowania przez nas stanowisk, ale też, nieuchronnie, do formułowania implikowanych przez tę siatkę paradoksów. Zwróćmy bowiem uwagę, czego tak naprawdę szukamy, chcąc rozstrzygnąć taki spór, jak ten między relatywizmem a absolutyzmem? Sama kategoria „rozstrzygnięcia”, należąca do siatki pojęciowej naszej kultury, nie jest semantycznie niewinna i klarowna. Szukając rozstrzygnięć czy też rozwiązań, nie przekraczamy horyzontu praktyki intelektualnej naszej kultury czy też pozostajemy jej graczami (tak jak „grę” pojmuje forma życia, w której uczestniczymy).

Sytuacja ta jest o tyle istotna $\mathrm{z}$ puntu widzenia nauk edukacyjnych, o ile zarówno relatywizm, jak i absolutyzm budzą nieufność intelektualną. Nie brakuje, na przykład, opinii, że

relatywizm ma niewygodne konsekwencje. Uprawomocniając zarówno własne, jak i obce standardy uzasadniania, osłabia krytycyzm, w tym autokrytycyzm, co może zachęcać do szowinizmu uprzywilejowującego własne poglądy lub permisywizmu tolerującego dowolne poglądy. Jedno i drugie nie sprzyja współpracy - interpersonalnej, międzypokoleniowej czy międzykulturowej (Grobler, 2013, s. 42).

Istotnie. Relatywista powinien nam odpowiedzieć na kilka pytań. Czy odróżnianie mądrych przekonań od niemądrych jest tylko kwestią przyjęcia jakiegoś pojęciowego układu odniesienia? Czy rzeczywiście jesteśmy

25 Myśl ta nie jest, oczywiście, nowa. Siatka pojęciowa, o której wspominam, ukonstytuowała się w zasadzie już w dziele Platona. Greccy sofiści byli również już tej siatki ostrymi krytykami. Współcześnie istotnych i znanych argumentów na rzecz porzucenia tej siatki, bądź poważnej jej rekonstrukcji, dostarcza między innymi Richard Rorty $(1999,2009)$. O jej niewydolności, w kontekście kryzysu idei zachodniego racjonalizmu, wspomina też Feyerabend (1987, 1999). W nieco innym kontekście jej krytykami byli choćby F. Nietzsche czy M. Foucault. 
skłonni uznać, że argumenty za tym, że Ziemia jest płaska są równie dobre jak argumenty współczesnych astronomów? ${ }^{26}$ Czy faktycznie nie istnieje absolutne kryterium racjonalnego rozstrzygnięcia między tymi argumentami? Czy nie ma sposobu uznania, że kultura, w której dopuszcza się torturowanie zwierząt i dzieci, jest w jakimś bezwzględnym sensie gorsza od kultury, w której takie praktyki są bezwzględnie i absolutnie potępiane i zakazane? Czy oddzielanie argumentów wnikliwych i trafnych od błędnych i szkodliwych jest kwestią jedynie kontekstu i konwencjonalnych standardów intelektualnych? ${ }^{27}$

Absolutysta jednak również stoi przed poważnymi problemami. Musi bronić się przed zarzutem intelektualnie autorytarnego forsowania wybranych przekonań, wartości i form argumentacji. Relatywiści zwracają uwagę, przywołując też historyczne przykłady, na niebezpieczeństwa absolutyzacji wybranych przekonań, standardów i opartych na nich praktyk społeczno-politycznych. Dla relatywistów wszelkie absolutystyczne interwencje w kulturę są intelektualnym i moralnym nadużyciem:

zarozumiali zbawcy muszą być świadomi, że mogą opierać się tylko na swoich utrwalonych przekonaniach oraz że żadne 'obiektywne' wartości nie przyjdą im z pomocą, gdy ich wysiłki zawiodą czy nawet pogorszą sprawy albo gdy zostaną potępieni przez przyszłe pokolenia, które wypracują odmienny konsensus moralny. My potępiamy Auschwitz i wielu z nas potępia decyzję Trumana o zrzuceniu atomowej bomby na Hiroszimę i Nagasaki, ponieważ takimi jesteśmy ludźmi, a nie dlatego, że mamy bezpośrednie połączenie z Niebem (Feyerabend 1987, s. 28).

Uznanie wybranych standardów za bezwzględnie ważne, poprawne i pożądane grozi zubożeniem, a w końcu zamarciem, wszelkiej krytycznej refleksyjnej debaty nad prawomocnością i ograniczeniami tych standardów. Co więcej, absolutyzm staje się w tej formie dyktaturą teoretyczną. Służy ona tylko tym, którzy mają poczucie, że oto stoją w obliczu absolutnych prawd oraz absolutnych norm. Opierając się na swoim poczuciu, absolutyści dają sobie prawo

26 Tego typu pytania stały się dość popularne w dyskusjach nad relatywizmem. Dlaczego relatywiści nie wyskakują na ulicę przez okna z wysokich pięter swoich uniwersytetów? Skąd bierze się ich przekonanie - zgoła nierelatywistyczne - że wiedza naukowa i technologia nie zawiedzie, gdy relatywiści latają samolotami na swoje konferencje? Por. na przykład Dawkins, 1995, s. 22-23.

27 Bezkompromisowej krytyki wszelkich form relatywizmu z punktu widzenia aksjologicznego absolutyzmu dostarcza choćby Joseph Ratzinger w swojej homilii podczas Mszy św. pro eligendo Romano Pontefice. Ku dojrzałości wiary w Chrystusa, gdzie stwierdza, iż „ustanawiany jest rodzaj dyktatury relatywizmu, która nie uznaje niczego za pewnik, a jedynym miernikiem ustanawia własne ja i jego zachcianki” (Ratzinger, 2005). Na marginesie, daje do myślenia fakt, że ostra krytyka relatywizmu przychodzi z dwóch tak, wydawałoby się, odmiennych stron, jak ateistyczny scjentysta Dawkins oraz głęboko wierzący teolog katolicki Ratzinger. Być może odmienność, o której tu mówimy, jest - na pewnym poziomie - pozorna. 
używać wybranych prawd i norm jako miary ludzkiej doskonałości i wskazówek co do tego, jakie życie ludzie powinni wieść ${ }^{28}$.

Dołączanie do naszych kategorii i wnioskowań epistemicznych i aksjologicznych predykatu „absolutny” bądź „relatywny” wydaje się czasem zabiegiem postulatywnym. Dołączanie to stanowi jedynie pewien intelektualny gest - wyraz pragnień, wyobrażeń i aspiracji. Wraz z argumentami, które, jak może się wydawać, wspierają racjonalność tego intelektualnego gestu, stosowanie konceptu „absolutności” bądź „,relatywności” ujawnia raczej rodzaj potrzeb egzystencjalnych tych, którzy skłonni są akceptować lub kwestionować ideę bezwzględnego ugruntowania ludzkich praktyk.

Jest bowiem tak, że argumenty i polemiki dotyczące relatywizmu bądź absolutyzmu, choć bywają intelektualnie wyrafinowane, nie wydają się wpływać na zmianę stanowisk uczestników sporu. Sam spór, owszem, ewoluuje. Po obu stronach przybywa subtelnych rozróżnień i interesujących przykładów oraz analogii. Strony reagują na argumenty adwersarzy, lecz nie opuszczają swoich stanowisk. Częściej zdarzy się przemilczeć lub zignorować trudny do odparcia argument przeciwnika, niż przyznać mu słuszność i zmienić się w relatywistę lub absolutystę. Oznacza to, być może, że spór relatywizmu z absolutyzmem ma też jakiś niejawny wymiar psychologiczny i egzystencjalny. Inklinacje do opowiedzenia się po którejś ze stron sporu wiążą się bowiem z naszym indywidualnym sposobem pojmowania fundamentalnych ideałów. Ideały te określają, co jesteśmy skłonni uznawać za porządek naturalny oraz kulturowy. Ta hipotetyczna skłonność określa w dużej mierze naszą, by tak rzec, wewnętrzną konstrukcję egzystencjalną. Konstrukcja ta nie ulega raczej zmianom w świetle czysto intelektualnych rozważań. Jest ona w znacznej mierze odporna na pojedyncze argumenty. Odpowiada bowiem za naszą ocenę mocy argumentów zaangażowanych w objaśnienie tego, co w danym momencie jest dla nas ważne, lecz niejasne. Poprzedza i determinuje ścieżki rozumowań, którymi jesteśmy skłonni podążyć, poszukując takiego rozwiązania danego problemu, które nie będzie wywoływało naszego niepokoju.

Do takich właśnie problemów należy, jak sądzę, filozoficzny spór relatywizmu $\mathrm{z}$ absolutyzmem. Ma on swoje rozbudowane teoretyczne werbalizacje, lecz jego sedno wydaje się tkwić głębiej. A to może oznaczać, że przemiana na przykład absolutysty w relatywistę może być nie tyle konsekwencją konkret-

28 Zaprzęgnięty w praktykę instytucjonalną taki absolutyzm jest w stanie dogmatycznie eliminować, jako szkodliwe zabobony, wolnomyślicielski dyskurs ikonoklastów. W najlepszym razie może pobłażliwie ignorować wielość perspektyw i postaw, które wielokrotnie w historii okazywały się źródłem postępu rozszerzającego świadomość i wrażliwość społeczną. 
nych teoretycznych argumentów, ile raczej mieć charakter nawrócenia. A to jest zwykle rezultat indywidualnego doświadczenia, nie zaś czysto intelektualnej deliberacji.

\section{Bibliografia}

Baghramian M. (2004). Relativism. Routledge, London-New York.

Barnes B. (1995). The Elements of Social Theory. PUP, Princeton.

Barnes B. (2004). On Social Constructivist Accounts of Natural Sciences, w: M. Carrier, J. Roggenhofer, G. Küppers, P. Blanchard (red.), Knowledge and the World: Challenges Beyond the Science Wars. Bielefeld University, Springer Verlag, Berlin-Heidelberg-New York.

Barnes B. (2011). Relativism as a Completion of the Scientific Project, w: R. Schantz, M. Seidel (red.), The Problem of Relativism in the Sociology of (Scientific) Knowledge. Ontos Verlag, Hausenstamm, s. 23-39.

Barnes B., Bloor D. (1982). Relativism, Rationalism and the Sociology of Knowledge, w: M. Hollis, S. Lukes (red.), Rationality and Relativism. OUP, Oxford, s. 21-47 (wyd. pol. B. Barnes, D. Bloor (1992), Relatywizm, racjonalizm a socjologia wiedzy, w: E. Mokrzycki (red.), Racjonalność i styl myślenia, tłum. M. Grabowska. IFiS PAN, Warszawa, s. 454-497).

Barnes B., Bloor D., Henry J. (1996). Scientific Knowledge: A Sociological Analysis. Athlone, London.

Bauman Z. (2003). Razem, osobno, tłum. T. Kunz. Wydawnictwo Literackie, Kraków. Bloor D. (1997). Wittgenstein, Rules and Institutions. Routledge, London-New York.

Bloor D. (2007). Epistemic Grace. Antirelativism as Theology in Disguise. "Common Knowledge", nr 13 (2-3), s. 250-280.

Boghossian P.A. (2006). Fear of Knowledge: Against Relativism and Constructivism. Clarendon, Oxford.

Bricmont J., Sokal A. (2004). Defense of a Modest Scientific Realism, w: M. Carrier, J. Roggenhofer, G. Küppers, P. Blanchard (red.), Knowledge and the World: Challenges Beyond the Science Wars. Bielefeld University, Springer Verlag, Berlin-Heidelberg-New York.

Carrier M., Roggenhofer J., Küppers G., Blanchard P. (2004). Introduction: Knowledge and the World: Challenges Beyond the Science Wars, w: M. Carrier, J. Roggenhofer, G. Küppers, P. Blanchard (red.), Knowledge and the World: Challenges Beyond the Science Wars. Bielefeld University, Springer Verlag, Berlin-Heidelberg-New York. Chmielewski A. (1997). Niewspótmierność, nieprzekładalność, konflikt. Siedmioróg, Wrocław. 
Collins H. (1985). Changing Order: Replication and Induction in Scientific Practice. CUP, Chicago.

Czerniak S. (1992). Względność poznania - problem zpogranicza epistemologii, w: J. Niżnik (red.), Pogranicza epistemologii. IFiS PAN, Warszawa.

Dawkins R. (1995). River out of Eden. Weidenfeld \& Nicolson, London.

Doppelt G. (2014). Best Theory Scientific Realism. „European Journal for Philosophy of Science", nr 4 (2), s. 271-291.

Durkheim E. (1990). Elementarne formy życia religijnego, tłum. A. Zadrożyńska. Wydawnictwo Naukowe PWN, Warszawa.

Evans-Pritchard E.E. (1973). Witchcraft, Oracles and Magic Among the Azande. OUP, Oxford.

Feyerabend P. (1987). Farewell to Reason. Verso, London.

Feyerabend P. (1999). Conquest of Abundance, B. Terpstra (red.). CUP, Chicago.

Fleck L. (1935). O obserwacji naukowej i postrzeganiu w ogóle. „Przegląd Filozoficzny”, nr 38, s. 58-76.

García-Carpintero M., Kölbel M. (red.) (2018). Relative Truth. OUP, Oxford.

Geertz C. (2000). Available Light: Anthropological Reflections on Philosophical Topics (wyd. pol. Geertz C. (2006). Zastane światło, tłum. Z. Pucek. Universitas, Kraków). Grobler A. (2000). Prawda a względność. Aureus, Kraków.

Grobler A. (2013). Prawda, jej namiastki i paradoksy z nimi związane, w: R. Ziemińska (red.), Przewodnik po epistemologii. WAM, Kraków, s. 19-52.

Grote J. (1865). Exploratio Philosophica: Rough Notes on Modern Intellectual Science. Deighton, Bell and Co., Cambridge.

Haack S. (1996). Reflections on Relativism: From Momentous Tautology to Seductive Contradiction. „Philosophical Perspectives”, 10, s. 297-315.

Habermas J. (1984). Theory of Communicative Action, vol. 1. Beacon Press, Boston.

Harre R., Krausz M. (1996). Varieties of Relativism. Blackwell, Oxford.

Herskovits M.J. (1955). Cultural Anthropology. A. Knopf. Inc. Ltd., New York.

Hesse M. (1974). The Structure of Scientific Inference. UP, Cambridge.

Hollis M., Lukes S. (red.) (1982). Rationality and Relativism. OUP, Oxford.

Jadacki J.J. (2002). Relatywizm karykatura racjonalizmu?. „Kwartalnik Filozoficzny”, t. XXX, z. 2, s. 131-139.

Jodkowski K. (1990). Wspólnoty uczonych, paradygmaty i rewolucje naukowe. UMCS, Lublin.

Kmita J. (1983). Kultura jako rzeczywistość myślowa, w: T. Kostyrko (red.), Teoria kultury a badania nad zjawiskami artystycznymi. Centralny Ośrodek Metodyki Upowszechniania Kultury, Warszawa, s. 15-30.

Kołakowski L. (1996). Nasz relatywny relatywizm, w: Habermas, Rorty, Kołakowski. Stan filozofii współczesnej, tłum. J. Niżnik. IFiS PAN, Warszawa. 
Kołakowski L. (2003). Husserl i poszukiwanie pewności. Znak, Kraków.

Kölbel M. (2011). Global Relativism and Self-Refutation, w: S.D. Hales (red.), A Companion to Relativism. Wiley-Blackwell, Oxford, UK.

Krug W.T. (2010/1838). Encyklopädisches Lexikon in Bezug auf die Neueste Literatur und Geschichte der Philosophie. Nabu Press, Leipzig.

Kuhn T. (1962). The Structure of Scientific Revolutions. CUP, Chicago.

Kusch M. (2002). Knowledge by Agreement: The Programme of Communitarian Epistemology. OUP, Oxford.

Kusch M. (2017). Epistemic Relativism, Scepticism, Pluralism. „Synthese”, nr 194 (12), s. $4687-4703$.

Lakatos I. (1977). The Methodology of Scientific Research Programmes: Philosophical Papers Volume 1. Cambridge UP, Cambridge.

Laudan L. (1996). Beyond Positivism and Relativism: Theory, Method, and Evidence. Westview Press, Boulder and Oxford.

Leszczyński D. (2013). Wiedza, relatywizm i sceptycyzm, w: D. Leszczyński (red.), Wiedza. „Studia Systematica”, 3.Wydawnictwo Naukowe Uniwersytetu Wrocławskiego, Wrocław.

Majcherek J. (1995). Relatywizm kulturowy. Uwarunkowania i konsekwencje pewnej doktryny. WSP, Kraków.

Margolis J. (1991). The Truth About Relativism. Blackwell, Oxford, UK.

Mokrzycki E. (red.) (1992). Racjonalność i styl myślenia, tłum. M.Grabowska, IFiS PAN, Warszawa.

Moroz J. (2018). Relatywizm. Pojęcie, rodzaje, podstawowe problemy. „Filozoficzne Problemy Edukacji”, nr 1, s. 1-14.

Motycka A. (1984). Relatywistyczna wizja nauki. IFiS PAN, Warszawa.

Norris Ch. (1997). Against Relativism: Philosophy of Science, Deconstruction and Critical Theory. Blackwell, Oxford.

Popper K.R. (1972). Objective Knowledge: An Evolutionary Approach. Clarendon Press, Oxford.

Popper K.R. (1994). The Myth of the Framework: In Defence of Science and Rationality. Routledge, London-New York.

Putnam H. (1987). Truth and Convention: On Davidson's Refutation of Conceptual Relativism. „Dialectica”, nr 41 (1-2), s. 69-77.

Putnam H. (1998). Wiele twarzy realizmu i inne eseje, tłum. A. Grobler. Wydawnictwo Naukowe PWN, Warszawa.

Quine W.V.O. (1953). From a Logical Point of View. Harvard University Press, Cambridge. Quine W.V.O. (1960). Word and Object. MIT Press, Cambridge, MA.

Quine W.V.O. (1969). Ontological Relativity and Other Essays. Columbia University Press, New York-London. 
Ratzinger J. (2005). Homily of His Eminence Card. Joseph Ratzinger, Dean of the College of Cardinals, Vatican Basilica, Monday 18 April 2005; www.vatican.va/gpII/documents/ homily-pro-eligendo-pontifice_20050418_en.html (dostęp: 9.03.2019).

Rorty R. (1999). Obiektywność, relatywizm i prawda, tłum. J. Margański. Wydawnictwo Fundacji Aletheia, Warszawa.

Rorty R. (2009). Przygodność, ironia i solidarność, tłum. W.J. Popowski. Wydawnictwo Fundacji Aletheia, Warszawa.

Roszyk M. (2015). Davida Bloora ujęcie opozycji relatywizm - absolutyzm. „Studia Philosophica Wratislaviensia", nr 10 (1), s. 7-22.

Searle J.R. (1995). The Construction of Social Reality. Allen Lane Penguin, London.

Seidel M. (2014). Epistemic Relativism: A Constructive Critique. Palgrave Macmillan, Basingstoke-New York.

Sojak R. (2006). Czy spór o relatywizm można rozstrzygać empirycznie?, w: P. Bytniewski, R. Chałubiński (red.), Teoretyczne podstawy socjologii wiedzy, t. I. UMCS, Lublin, s. 287-301.

Sokal A., Bricmont J. (2004). Modne bzdury. O nadużyciach nauki popetnianych przez postmodernistycznych intelektualistów, tłum. P. Amsterdamski. Prószyński i Sp., Warszawa.

Szahaj A. (2011). Nauki o kulturze jako nauki podstawowe (i krytyczne). „Filo-Sofija”, nr 12 (1), s. 183-188.

Whorf B.L. (2002). Język, myśl i rzeczywistość, tłum. T. Hołówka. KR, Warszawa.

Więcław M. (2005). Uwagi o pojęciu obiektywności wiedzy, w: K. Zamiara (red.), Kultura. Komunikacja. Podmiotowość. UAM, Poznań.

Winch P. (1964). Understanding a Primitive Society. „American Philosophical Quarterly”, vol. 1, nr 4 (wyd. pol. Rozumienie społeczeństwa pierwotnego, w: E. Mokrzycki (red.) (1992). Racjonalność i styl myślenia, tłum. M. Grabowska. IFiS PAN, Warszawa). Wittgenstein L. (2000). Dociekania filozoficzne, tłum. B. Wolniewicz. Wydawnictwo Naukowe PWN, Warszawa. 